\title{
Certain Observations on the Pineal Organ of Indian House Crow, Corvus splendens (Vieillot) during Annual Cycles
}

\author{
B. C. Chauhan* and P. M. Ambadkar*
}

\begin{abstract}
Pineal glands have been studied for seasonal histological variations. Structural details of the pineal gland of the Indian house crow have been described. The gland could be more correctly described as "INTERMEDIATE" (i.e. sacculofolicular) between the compact lobular and saccular types found in other vertebrales. Anatomical observations on different cell-types and nerve supply have been recorded. Annual variations in glands' weight, and the changes in nuclear populations have been observed and correlated with simultaneous changes occurring in the day length and gonadal activity. It has been observed that the pineal gland was more active during regressive and the non-breeding phases of gonads (short-day length regimen) than during the breeding phase (long-day length regimen). Volume changes per si were found to be less significant in assessing the state of activity of the gland.
\end{abstract}

A recent resurgence of interest in the vertebrate pineal organ of epiphysis cerebri has provided new evidence about its systematic diversity as well as its probable functional significance in birds (Ralph 1970, 1978). Although embryologically derived from the roof of the diencephalon, the pineal organ of birds shows a remarkable variety in size, form and structure (Studnicka 1905, Tilney \& Warren 1919, Bargmann 1943, Shellabarger 1952, Quay \& Renzoni 1963, 1967; Quay 1965a, Renzoni 1965 a, b, 1970; Wurtman et al. 1968, Ralph \& Lane 1969, Dodt et al. 1971, for review see Menaker \& Oksche 1974). More attention has been directed recently towards avian pineal structure and its functional significance as a neuroendocrine organ (Wurtman et al. 1968, Ellis 1976, Hartwig 1980, Binkley 1980, Reiter 1980). Most of the recent work involving electron microscopic and experimental work (concerning photoperiodism, effects of melatonin and extirpation of the pineal gland, etc.) points to endocrine activity of the specific pineal parenchymal cells or pinealocytes. Histophysilogical studies have shown that, in general through the vertebrate series, as pineals' photoreceptive activity decreases, an apparent secretory capacity increases (Quay 1970a, 1972a, b). Among birds only abortive or vestigial photoreceptors have been identified so far in electron microscopic studies of the pineal organ (Oksche \& Vaupel-von Harnack 1965a, b, 1966; Collin 1966a, b, c, 1967a, b, 1968, 1969, 1971; Renzoni et al. 1968, Bischoff 1967, 1969; Oksche et al. 1969, 1971, 1972; Oksche \& Kirschstein 1969, Oksche 1968, 1971; Mikami 1969). Electrophysiological investigations have been unsuccessful in detecting any discrete response to light by avian pineals (Morita 1966, Ralph \& Dawson 1968).

Received 8 August 1983

* Division of Neuroendocrinology, Department of Zoology, Faculty of Science, M.S. University of Baroda, Baroda, Gujarat State-390 002, India. 
Two tacit assumptions seem to have gained undue strengths during the search for basic and general characteristics in avian pineals (Quay \& Miller 1971). One of them, that species differences are slight is strongly contradicted by detailed simultaneous studies of pineal ultrastructure in different species of birds (Quay \& Miller 1971). The other assumption that regional differences within a pineal gland are minimal, apparently ignores the extensive and quantitatively more significant evidence to the contrary derived from light microscopic studies (Hollman 1962, Quay 1965a). Recognition of these differences is self significant in the description of pineal cellular changes elicited in experimental studies and in the design and interpretation of experiments in which the pineal is partly or wholly extirpated.

Rapid biochemical changes occurs in avian pineal organ in close correlation with the daily timings of environmental illumination (Axelrod et al. 1964, Quay 1966, 1970a; Ralph et al. 1967, Hedlund \& Ralph 1967; Lauber et al. 1968, Saylor \& Wolfson 1968, 1969; Binkley 1980). These changes are thought to be most likely mediated via the innervation of the pineal which is activated as a consequence of photoreception by the lateral eyes. The biochemical changes in the pineal gland have been postulated to be presumably related to pineal endocrine activity which many have some physiological significance in relation to adaptation to photoperiodicity either on a short term (Binkley 1980 ) or on a seasonal basis (Barfuss \& Ellis 1971). However, such a latter postulation is obviously in need of extensive additional supporting evidence. With recent advances pertaining to the knowledge about structural organization of avian pineal and its primary photoperiodic responses in context to varied environmental photoperiodic conditions it becomes interesting to study the functional role of pineal in one species inhabiting different regions. In the light of the above consideration it would be very appropriate that the study of pineal gland of a bird like the Indian House Crow (Corvus splendens) whose breeding season differs in different regions of varied environmental conditions, could provide interesting information about the pineal physiology, Published descriptions of corvid pineals are scanty. Sexual activity, of both male and female house crows in Baroda (Lon. $73^{\circ} 13^{\prime} \mathrm{E}$; Lat. $22^{\circ} 18^{\prime} \mathrm{N}$ )-Western India, is remarkably restricted to a single breeding period in an year to a month and a half viz. June to mid-July. Nevertheless, regional differences do exist in the timing of reproductive activity of this species (for references see Ambadkar \& Chauhan 1976, 1977, Chauhan 1978). Considering the continuously growing experimental evidence in favour of association of the avian pineal with rhythmic photoperiodic and sexual response mechanisms, an investigation of possible involvement of pineal gland of the Corvus splendens in the regulation of seasonal reproductive activity would be of interest. Hence, the present investigation was initiated to acquire information in good details about structural plan of pineal gland and seasonal changes in it of the Corvus splendens as a prerequisite, since such is apparently not available.

\section{Material and Methods}

Hundred and eighteen Indian House Crows (54: Females and 64: Males), obtained near Baroda (India) from Jan. 1,1970 to Aug. 16, 1976, were studied. Majority of the 
birds were shot down on the University Campus and few were secured alive from local dealer. Birds were weighed and decapitated. Brain was dissected out and pineal organ was carefully detached from the roof of diencephalon. Choroid plexus was removed under dissection microscope. The pineal organ was then blotted free of tissue fluid and an estimate of the actual pineal weight was determined by weighing the fresh glands on Metler balance and no less than 5 birds of each sex at any given time were used for this purpose. In few cases, pineal was fixed in situ after trimming the sides of the brain. After fixation for 24 hours and due processing, the glands were embedded with such orientation that sections could be cut in the sagittal plane. Serial sections were cut at 5- $\mu$ and stained variously with hematoxylin-eosin, Azan's stain and PAS-technique. A few sections were processed for demonstration of acetylcholinesterase activity and few other were treated with silver impregnation method to localize nervous elements.

An estimate of differential cell populations of the pineal was made by recording the population densities of the nuclei per unit area of various cell types. For each pineal, the nuclei per unit area within an occular grid in ten random fields from both the central and peripheral areas in the distal part of the gland were counted. Since the density was almost the same in both areas the average was taken as the density. Nuclei of the parenchymal (pineal) cells and of non-parenchymal or "stromal" (arbitrarily suggested term) cells were counted. Among the latter category were included nuclei of fibrous, mast, nerve and connective tissues since it was often difficult to differentiate these cells with respect to their nuclear morphology.

The volume of the pineal gland was measured by a method followed by Takashi and Matsushima (1967), which was essentially the same as that used by Izawa (1925) for rats and by Stalsber (1966) for chickens. In each month three birds of each sex were considered in the determination of pineal volume. The average size of nuclei (of pinealocytes) was recorded with the help of occular micrometer at high mangification. Data for variations in day lengths and embient temperature during the study period were gathered from University observatory and are graphically expressed in Fig. 3.

\section{Observations}

\section{MORPHOLOGY:}

The pineal gland or epiphysis cerebri of the Indian House Crow, is intracranial in location and is situated on the dorsum of the brain superficially, lodged in a triangular space between the cerebral hemispheres and cerebellum. In dorsal view the pineal gland could be seen as a traingular body with the apex pointing anteriorly. In the lateral view it presented a shape like that of an inverted pyramid. It is covered by the overlying meninges. It may easily be seen by exposing the transverse depression and the external sagittal groove of the calvarium. Beneath the point of intersection of these grooves lies the pineal. Its mid-sagittal sections showed ' 7 ' shaped outline (Fig. 4). The rostrocaudal length of crow's pineal (male as well as female birds) ranged from 1.30 to 1.94 $\mathrm{mm}$ (mean $=1.03 \pm 0.82 \mathrm{~mm}, \mathrm{n}=26)$. Sagittal section revealed following easily recognizable parts:-a proximal narrow stalk and a dorsally located broad distal part (Fig. 4). 
The gland was seen to be encapsulated by a thin layer of connective tissue which was closely associated with the meningeal layers near the dorsal aspect of the gland. This capsule was composed of collagenous fibers, which formed delicate septules. The latter were most notable for they contained blood capillaries. Although fibroblasts were frequently seen, macrophages and mast cells could not be identified so easily, presumably due to non-specificity of the staining techniques employed. Occasionally, mast cells were observed generally located adjacent to the blood vessels. The intra-pineal septa were abundant, particularly in distal part of the pineal gland, where a compact organization of the pineal cells was much more evident. The follicles or rosettes of cells in the distal part were surrounded by thin inter-follicular trabeculae arising from the surrounding capsule. Follicles present in the stalk have wider lumina than those noted for follicles of distal part (Fig. 4). Pineal epithelium of the stalk was found to be infolded forming scalloped lining at many places (Figs. $4 \& 5$ ).

\section{Stalk:}

At the ventral apex of the pineal gland, the connective tissue of the capsule along with pineal mass tapered into a slender proximal part-a 'stalk', which was connected with the diencephalic roof of the brain. The pineal stalk was a hollow structure lined by columnar epithelial cells. Since height of the stalk was considerable, the distal more solid part of the gland was raised noticeably above the diencephalic roof of the brain and was brought closer to the cranial roof. There was some attenuation of lumen at the junction of the distal part of the gland and the stalk. In this region, the epithelium of stalk showed considerable, though variable, cellular proliferation and a concomitant increase in the size of folds, which seemed to be more extensive here comparatively than elsewhere in the gland. The region between the diencephalic roof and bottom of the stalk of the gland was particularly occupied by parenchymal cells (hypendymal cells), which were compact in arrangement and hence the glandular lumen in this region was obliterated and did not communicate with the third ventricle (Fig. 4). The most obvious and dominating aspect of the structure of the stalk was the presence of tractus pinealis which courses through its posterior wall.

\section{Vascularization:}

The posterior meningeal artery was seen to arise near the choroid plexus as a branch of the cranial ramus of the left carotid artery. This blood vessel was observed to enter the pineal capsule at the basal part of the gland proper and to run along the anterolateral surface. This vessel was seen to give out smaller branches in the pineal substance and course upto the meninges at the dorsal surface of the anterior part of the pineal gland. At this place the artery was observed to turn posteriorly and small twigs were given out to supply the rete pinealis of the pineal gland. A branch of the cranial ramus of the left internal carotid artery was seen to form a circus vasculosus (Baumel 1962) at the base of the gland. The rete pinealis formed a complex vascular network supplying the whole gland. These fine vessels were observed to traverse the pineal trabeculae. This complex vascular network could provide a rich blood supply to the pineal gland, and this appeared to be a characteristic feature of the birds. Venous outflow seemed 
to be provided by large venules located in comparatively thicker trabeculae. Small meningeal blood sinuses were seen dispersed along the inner surface of the pineal capsule.

\section{Pineal Organization:}

The pineal gland proper presented a varying degree of structural organization ranging between saccular to sacculofollicular structures. Occurrence of saccular glands were obtained only for two crows during the period from August to December. Most of the birds however, exhibited sacculo-follicular structure but none had compact lobular (i.e. solid or parenchymal type) organization. Statistical comparisons of the percentages of luminal areas of the saccular pineal (mean $=22.3 \pm 10.8 \%, \mathrm{n}=2$ ) and the sacculofollicular pineal (mean $=15.4 \pm 9.6 \%, \mathrm{~N}=3$ ) showed significant differences. Histological appearance of gland revealed two parts: (1) a proximal part, in connection with the diencephalic roof, known as pineal 'stalk' and (2) a 'distal' part found more dorsal towards the roof of skull. It is worth mentioning here that a complete or incomplete septum, that has been reported to separate the stalk from the pineal gland proper (distal part), was not observable in the Indian House Crow.

\section{Cell Types:}

In the literature on pineal cytology a number of terms are in currency and to avoid confusion and impreciseness it was thought desirable to clarify the meaning of the terms used here. Alpha pinealocytes are cells that line the luminal sides and are variously described as 'ependymal cells', 'rudimentary photoreceptor cells', 'photosensory/ neurodendocrine cells' etc. These were flask-shaped with a clube-like apical protrusion ("lamellar bodies", Menakar \& Oksche 1974, Wurtman et al. 1968) extending into the lumina (Figs. 5, 8 and 9). The bodies of these cells had three distinct regions: (1) a basal region (2) a narrow neck or colliculus region and (3) an apical or outer segment known to possess degenerating or rudimentary photo-receptor laminations. This cell-type was much more abundant than the supportive type of pinealocytes. Nuclei are large and spherical or oval in shape. Normally, pinealocyte height ranged from 15 to $27 \mu$ (annual mean $=21 \mu$ for both the sexes). Eosinophilic granules were present at the apical portion in majority of the cells. Vestigeal apical protrusions of these cells exhibited varied shapes and were weakly PAS positive (Fig. 8). The supporting cells (Basal Cells) are found scattered among the $\alpha$-pinealocytes that form the linging of lumina (Figs. 5, $6 \&$ 8). These cells also known as $\beta$-pinealocytes, which differ from the former type owing to conspicuous absence of "outer segment" that is characteristic of $\alpha$-pinealocytes. The nuclei of these cells are generally small and show wrinkled outlines. $\beta$-pinealocytes are also known as "parenchymal cells" or "hypendymal cells". $\beta$-pinealocytes compose the main bulk of the gland and are always localized away from lumina. Their nuclei often show irregular shapes due to inveginations of the nuclear membrane. Cell boundaries are indistinct. Cytoplasmic region stains extremely faintly and is very often agranular. It is weakly PAS positive.

Occurrence, relative distribution, and other features of these cells in pineal organization of the Indian House Crow are described in the following paragraphs.

Morphological and histological appearance of the proximal and distal parts of the 
gland exhibited different patterns. The proximal part as characterized by: (a) a large central lumen exhibiting a well define epithelial lining (Figs. 5, 7 and 8), (b) consisting of more of $\alpha$-pinealocytes and presence of less of $\beta$-pinealocytes occasionally forming a few follicles in the wall of the stalk, (c) many non-myelinated nerve fibers along the posterior wall of the stalk and a number of nerve cells located in the form of a layer subjacent to $\alpha$-pinealocitic lining around the basal (bottom) portion of the stalk. The distal part had the following characteristics: (a) in general, a compact arrangement having follicles was more apparent. Whenever residual lumina were observed, the lining of such lumina exhibited degenerative or less prominent outer segments of $\alpha$ pinealocytes (Fig. 6), (b) There was a much greater increase in the number of parenchymal cells or the $\beta$-pinealocytes, relatively very low occurrence of $\alpha$-pinealocytes, which with $\beta$-pinealocytes form better defined follicles, (c) a few non-myelinated nerve fibres. These characteristics gave the distal part a more solid appearance than the lower part (i.e. stalk) of the pineal gland.

\section{Innervation:}

Numerous branched non-myelinated fibres were found. These fibres were mostly localized in the proximal part of the gland and in the postero-distal portion of the pineal stalk. Few fibres could be found even in the other locations of the pineal gland. Some fibres were observed to surround, while a few others were seen to traverse the intercellular spaces in the follicles (Fig. 8). They were most abundant at hypendymal level of the epithelial lining. The autonomic nerve fibers in the connective tissue fo the pineal capsule were seen to be arranged in small bundles. Few fibers could be seen to accompany the capsular blood vessel and presumably they were sympathetic fibers (Quay \& Renzoni 1963). The parenchymal cell complex was observed to be innervated by the fibers that were located primarily in the interlobular ( $=$ trabecular) areas. Some of the nerve cells (Fig. 8) in the stalk region were noticed to send fine fibres arranged in looplike manner seemingly reaching or terminating at the basal regions of the $\alpha$-pinealocytes (Fig. 9) and also possessing similar fibers merging into the outer reticular area. The outer reticular area was comprised of small round cells (strongly impregnated) subjacent to the layer of $\beta$-pinealocytes and the fibers emanating from them were observed to run longitudinally around the proximal region of the pineal stalk.

Moreover, acetylocholinesterase-positive neuronal structures in the pineal organ of Indian House Crows were observable. These were found to occur in increasing numbers towards the stalk portion of the organ. Profiles of acetylcholinesterase positive neurons and nerve fibers were evident in the form of a nervous tract (tractus pinealis), in the posterior wall of the pineal organ.

\section{Cyclic Changes:}

From the values expressed in (Fig. 1) it is clear that no cyclic or seasonal variations of any significance in regard to pineal volume could be discerned. Pineal volume, except for minute variations, remained practically constant for both the sexes of crow throughout the year. The pinealocytes and stromal cells (other than pinealocytes) remained almost unaltered in population density throughout all the periods (Fig. 2). The 


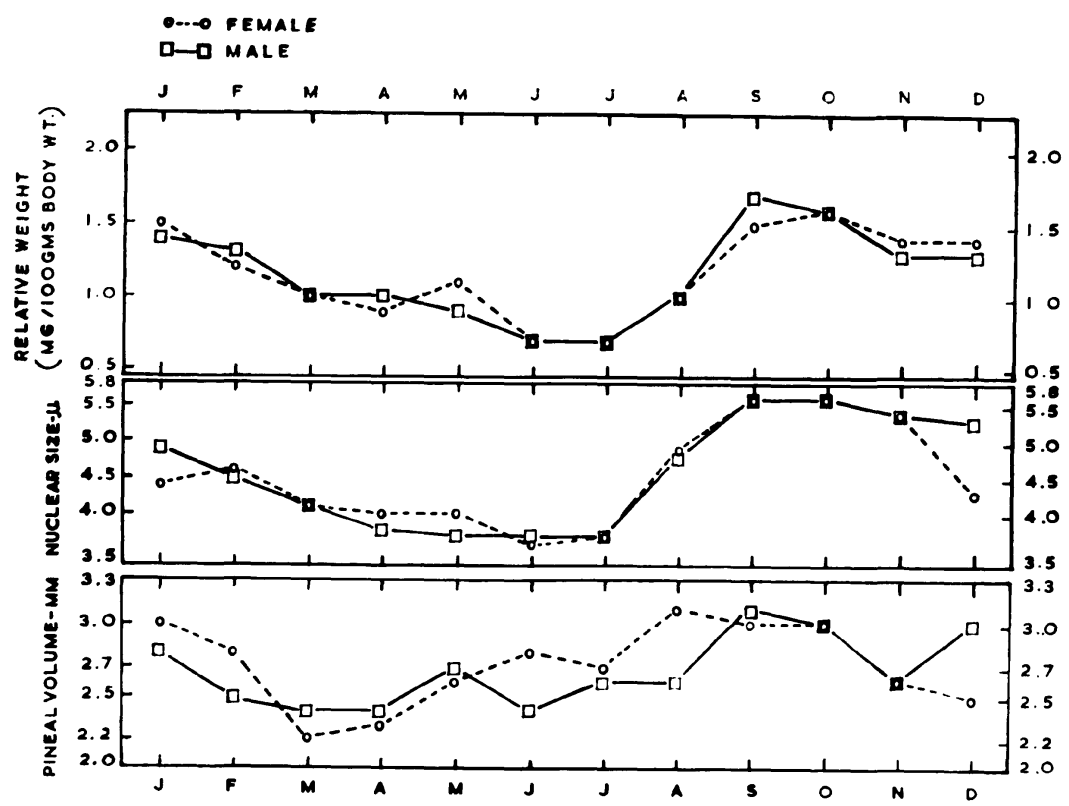

Fig. 1. Graph showing annual variation in pineal volume, nuclear size and relative weight.

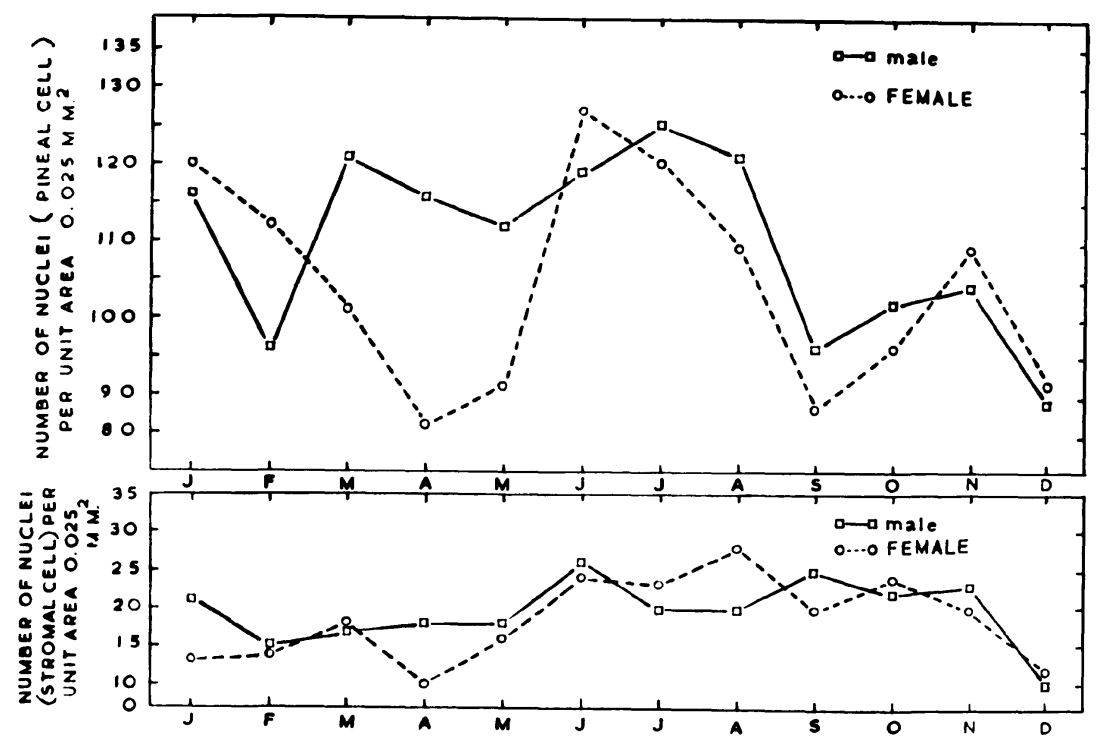

Fig. 2. Annual variation in nuclear density of pineal and stromal cells.

variation in number of nuclei per unit area occupied by pinealocytes and that by the stromal cells was of such nature that it was difficult to derive any plausible correlation regarding their populations in a unit area. 
Lowest pineal weights have been recorded during June and July for both the sexes (Fig. 1). An abrupt increase in weight was noticed in August and it reached maximum value in males in the months of September and in female in October. Thus, it was evident that the lower weights were recorded during the breeding period (i.e. June and July) and higher weights during regressive phase (in females: incubation and nesting period) (for details on gonadal cycle see Ambadkar \& Chauhan 1976, 1977). Pinealocyte nuclear size variations too, like the variations in pineal weights showed one-peaked cycle throughout the year. The peak in nuclear size was recorded during September and October while the lower values were recorded during June and July. The trend in pinealocyte nuclear size variation of the female crows differed slightly than that recorded for the male crows. In female birds, the fall in weight began by the end of May (end of the nest building period) whereas in male birds the fall in the same was earlier i.e. from the end of April. Annual mean weights (absolute as well as relative \% body weight) showed slightly heavier pineals for female crows, otherwise there were no sex differences encountered during this study.

\section{Discussion}

\section{Morphology and Anatomy:}

The pineal glands of $C$. splendens were large in comparison with other passerine birds (Quay \& Renzoni 1963). Quay $(1965,1972)$ has shown that differences in avian pineal size were not wholly related to animal size or brain size. However, that larger birds have larger pineal glands is still true in a general sense, except in a few birds, where the pineal was found to be almost absent (Krabbe 1961, 1965; Quay 1966 and authors' unpublished observations).

Pineal of the Indian House Crow was morphologically similar to that described in case of other Corvids viz., Corvus monedula, Corvus corone and Corvus corax (Renzoni 1965a, Quay \& Renzoni 1967), and, also to the pineals of many other passeriform birds (Studnicka 1905, Tilney \& Warren 1919, Krabbe 1965, Renzoni 1965a, 1970; Oksche \& Vampel-von-Hearnack 1966, Quay \& Renzoni 1967, Collin 1969, Quay 1965, 1972; Hartwig 1980). All these pineals like that found in this bird, had a residual lumen varying in its degree of ramification and a narrow slender pineal stalk connected to the roof of the third ventricle.

Like some other passerine pineals, the Indian House Crow pineal had a lumen, but there was no connection between the lumen of the gland proper and the third ventricle. It seems improbable, therefore, that secretory material, if there is any, passes directly from the lumen of the pineal gland to the third ventricle, at least in the adult birds. Conditions may be different in other birds, where some species showed a permanent connection between the pineal lumen and the third ventricle (Qauy \& Renzoni 1967, Leonhart 1978). It is interesting to note here that Pang (1971) reported that the pineal stalk of Scrub Jay (Aphelocoma coerulescens) has no apparent anatomical connection with the diencephalic roof.

Accessory or secondary pineal parenchymal masses in the form of relatively small nodules or follicles were present at the basal part of the stalk in a number of birds studied 
by Quay and Renzoni (1967). The parenchymal accessory structures reported to be present in adult columbids have been considered as probable remnants of secondary evaginations. Krabbe (1965) described a "parietal corpuscle" detached from the pineal organ in the swan which he suggested to be a homologue of the parietal eye of lizards. Later on, the same author noted a vesicular distal swelling on the parakeet epiphysis which was regarded by him as a reminiscence of the rudimentary eye. In few cases, lymphoid accumulations were reported to be associated with this organ (Spiroff 1959; Krabbe 1965, Quay \& Renzoni 1963, Quay 1965a). Neither accessory pineal tissue nor lymphoid tissue was observed in the Indian house crow.

Intermediate forms of varying degrees between saccular and sacculo-follicular pineal glands have been observed during the present study on this bird (Corvus splendens). A typical saccular pineal organ is depicted as a hollow organ with folds and local proliferations in its wall as reported in passerine birds (Studnicka 1905, Tilney \& Warren 1919, Bargmann 1943, Quay 1965a), whereas a generalized follicular pineal gland possesses a system of follicles and/or tubules (as observed in the pineals of chicken and duck). Mammalian pineal is generally described as 'solid-parenchymal' or 'compactlobular' type. It is interesting to note that in only two crows, collected during post breeding phase, had a SACCULAR TYPE of pineal, thus the frequency of occurrence of such pineal forms, was low. It is presumed that such a change in form might be related to age and/or different physiological conditions. Correlation between pineal size and age as reported by Ralph and Lane (1969) was not tested in case of the house crows during this study, however, further investigation in this line might reveal interesting information. The abundance and location of nerve fibers in the pineal substance of the house crows were similar to that reported in other avian pineals (Quay \& Renzoni 1963, Kappers 1965, Pang 1971). The degree of vascularization of the pineal in itself is no indication of secretory function. Nevertheless, considering all feature (parenchymal composition, organization, luminal attenuation, blood supply, innervation etc.) of the pineal of this species-Corvus splendens, it is tempting to consider the possibility of secretory function in this case. The arterial supply to the pineal of the House Crow was similar to that of adult pigeon (Baumel 1962), chicken (Beattie \& Glenny 1966) and Scrub Jay (Pang 1971). Though more precise knowledge was not obtained on this aspect yet the rich rete pinealis vascular network observed in the pineal of the House Crow, could possibly serve as an effective route for pineal hormone(s) transpiration, as was suggested by Quay and Renzoni for other birds (Quay \& Renzoni 1963, Quay $1965 \mathrm{a}, \mathrm{b})$. If this is the case, it is possible that pineal inducer(s), polypeptide(s) and/or indole(s) may have significant influences on the central nervous system, and the notion that the action of the pineal is on the brain tissue (Quay 1970b, 1973) becomes more convincing. Cheze and Lahaye (1969) have presented evidence of not only photic influence on the secretory activity in the pineal of Gambusia affinis but have also described some functional relationship with the choroidal epithelium. A physiological interaction between the choroid plexus and subfornical organ in Rana temporaria and Rana esculenta has been reported by Srebro (1967 a, b). In fact, Friedrich-Fresksa (1932) was the first to suggest that in Coregonus and Dermogenys, secretion from the pineal possibly controls permeability of the choroid plexus and eventual modification of secretion of 
cerebrospinal fluid. In the light of the anatomical association of the pineal with the brain and the third ventricle it is possible that intramural functional relationships among these structures may be of greater significance. Moreover, there is no evidence as yet for any portal or other specialized intracranial systems that could direct pineal blood flow to any particular brain regions, choroid plexi or other intracranial structures (Gladstone \& Wakeley 1940, Le Gros Clark 1940, von Bartheld \& Moll 1954, Kappers 1960, Smith 1971, Quay 1973). Pineal's endocrine effects on the central nervous system have been reported by many (Bindoni \& Rizzo 1965, Quay 1965b, 1973; Collin 1966 a, b, c, 1967 a, b, 1969, 1971; Renzoni et al. 1968, Mikami 1969, Ueck 1970, Nir et al. 1969a, Anton Tay 1971). In the light of such observations regarding possible endocrine status of the pineal gland it becomes all the more significant to await further investigations deploying advanced experimental procedures to dwell upon the problem of probable routes of transport mechanisms between the gland and the brain itself. Whether the $\alpha$-pinealocytes of the Indian House Crows are structurally homologous to the 'photoreceptor' vestigial photoreceptor cells described in the case of many animals (Eakin \& Westfall 1959, 1960; Kelly 1962, Dodt 1963, Hafeez \& Ford 1967, Fujie 1968, Wurtman et al. 1968, Collin 1971, Hafeez 1971, Oksche 1971, Menaker \& Oksche 1974, Menaker \& Zimmerman 1976) or do they seemingly correspond to 'sensory' cells as described by Quay and Renzoni (1963) for many other avian species, nothing conclusive can be said in this regard on the basis of present light microscopic observations. It is hoped that EM and certain histochemical studies on this will help to derive any conclusion regarding terminology and comparison, for pineal cell types in question. However, it is interesting to note that the photoreceptor cells that bear regularly lamellate outer segments are lacking in birds, whereas numerous vestigial photoreceptor cells exhibiting morphological signs of secretory activities occur in birds (c.f. Oksche \& Hartwig 1979, Hartwig 1980). $\alpha$-pinealocytes of crow's are perhaps similar in structure and function to photosensory/neuroendocrine cells described for avian pineals by Hartwig (1980).

\section{Cyclic Changes:}

Exposure of animals to constant light has a certain inhibitory effect on some of the metabolic processes of their pineal glands. It is known to cause a decrease in levels of melatonin (Tomatis \& Orias 1967), serotonin (Quay \& Halevy 1962, Binkley 1980), 20\% decrease in lipids (Quay 1961, Prop \& Ebels 1968) and glycogen (Quay 1963). Exposure to prolonged illumination is also known to cause marked decrease in the activity of several pineal enzymes-e.g., 5-hydroxyindole-O-methyltransferase (HIOMT) (Wurtman et al. 1963, Axelrod et al. 1965, McGeer \& McGeer 1966, Barfuss \& Ellis 1971, Binkley 1980), N-acetyl-transferase (NAT) (Binkley 1980), succinic dehydrogenase (Quay 1963) and tyrosin hydroxylase (McGeer \& McGeer 1966). On the other hand, activity of 5-hydroxy tryptophan decarboxylase, the enzyme which makes serotonin, has been shown to increase (Tomatis \& Orias 1967).

Roth et al. (1962) found that constant illumination decreased the size of the pinealocytes, pinealocyte nuclei, and cytoplasmic basophilia by about 20 to 30 percent. Other investigators (Wurtman et al. 1963, Prop \& Ebels 1968) have interpreted their findings in regard to the same experimental conditions as indicative of a decrease in RNA 


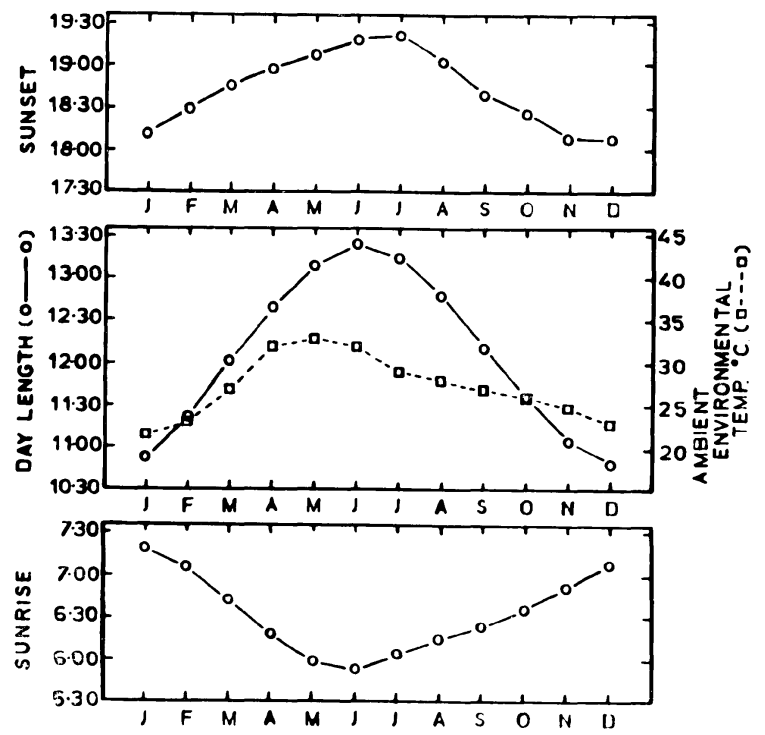

Fig. 3. Showing mean monthly time of sunrise and sunset, day-length, and ambienttemperature prevailing at the study area (Baroda, Western India) for the period of study (1970 to 1973).

synthesis in pineal glands. Furthermore, Nir et al. (1969b) provided direct evidence of decreased RNA synthesis with a corresponding reduced protein level, which presumably indicated that continuous light inhibits the general metabolic activity of the pineal organ. Their findings led them to suggest that light acts on protein synthesis at the ribosomal level. Reduced RNA/protein synthesis may explain the diminished pineal weight of animals exposed to constant light (Fiske et al. 1960, Wurtman et al. 1961, Fiske et al. 1962, Tomatis \& Orias 1967). So far, little is known about the cellular metabolism through annual variation in the weight and other changes of the pineal upon exposure to natural long day or short day periods. In light of the above reports, an attempt has been made here in the following paragraphs to correlate the present findings with regard to the influence of natural variations in the day length at Baroda (India) (Fig. 3) on pineal activity as related to the reproductive cycles. Karyometry has been held to be useful in the assessment of changes in the activity of cells. If a cell is affected in some way, its metabolism will change and this is manifested as changes in the cell structure (Casperson 1950), and also the nuclear volume. A change in nuclear volume observed in Karyometric observations thus, indicates an alteration in metabolic activity of cells. Karyometry can tell us nothing of the quality of change in activity. Nevertheless, variation in the nuclear volume of a secretory cell may apparently be considered as an index of a change in its secretory activity. Generally an increase in nuclear volume is associated with increased activity, while a decrease in volume corresponds to diminished activity (Benninghoff 1953, Szentagothai et al. 1962, 1968; Talanti 1967). Provided that the above concepts on the influence of functional activity upon nuclear volume are 
correct, it would seem that the present observations on the pineal cells presumably indicate considerable increase in pinealocyte activity during mid-August to November months (Figs. 1, 2). On the other hand, a prominent decrease or reduction in nuclear size of the pineal cells, that commenced in the month of May and continued through June and July, reflected a decrease in cellular activity (Figs. 1, 2). Decrease in nuclear size of the order of $30.25 \%$ and $25.45 \%$, in case of male and female crows respectively (mean value for August to December Vs mean value for April to July) and a concommittant in-

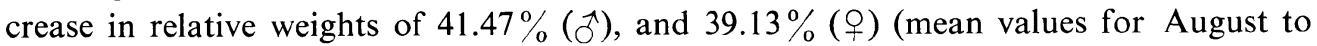
December Vs April to July) of pineal organ of the crow were easily discrenible (Fig. 1). On the basis of this, following conclusion can be drawn:-That, there was noticeable reduction in the gland's activity during relatively longday length periods (Figs. 1-3) and that an enhancement was apparent in the cellular activity during shortday length periods. As noted here, decreasing pineal weights during longday length period (i.e. June and July) could imply minimal or suppressed synthesis of protein/RNA by the pineal of house crows. Contrastingly, enhanced synthesis of protein/RNA presumably caused an increase in pineal weights during short-day length period (i.e. August to December).

The DNA content of the pineal gland is not affected by continuous light (cited by Nir et al. 1969b), as the amount of DNA per diploid cell (nucleus) of a given species is constant (neurons, glial cells and pinealocytes are essentially diploid). Thus, it has been suggested (Nir et al. 1969b) that DNA determination may be used as an index of the number of pineal cells. Finding of Nir et al. (1969b) would thus imply that the reduced pineal weight observed in animals exposed to continuous light is brought about by inhibition of the parenchymal hypertrophy, and not by reduction in the number of cells. Indeed, histological studies have shown that the parenchymal cells in pineal of animals exposed to continuous light have smaller nuclei and a reduced cytoplasmic volume (Roth et al. 1962). Moreover, pineal parenchymal mitosis is known to be very rare in adult animals (Quay \& Levine 1957, Quay \& Renzoni 1966). Similar observations have also been noted during present study in regard to occurrence of mitosis. It has been found (Izawa 1925, Quay \& Levine 1957, Takashi \& Matsushima 1967) that the volumetric growth of the pineal in postnatal life, except for early life, is mainly due to hypertrophy of the parenchymal cells. The present study on pineal of Indian House Crow $(C$. splendens) indicated no proliferative activity. Thus increase in weight noted during September to January was presumably due to hypertrophy of pinealocytes. The above view finds support in the fact that no significant cyclic variations in the pinealocyte population density could be observed (Fig. 2).

The population density of the "stromal" cells remained almost constant throughout the annual cycle and the population itself was small as compared with that of the pineal cells. The data obtained (Figs. $1 \& 2$ ) presumably suggested that the volumetric increase observed in the pineal organ of the Corvus splendens is associated primarily with the pinealocytes rather than with the stromal cells.

By way of summarizing as to what presumably takes place within the pineal of $C$. splendens during the longday length regimen, the following may be stated:- - Light stimuli that reach the pineal gland via the nerve endings to the pinealocytes (Quay \& Levine 1957, Wurtman et al. 1964, Axelrod et al. 1965, Ellis \& Balph 1976) could probably 
reduces activity of transfer RNA followed by a corresponding decrease in protein synthesis and enzymic and other proteins of the cells. Thus both reduced protein and enzyme formation could cause a decrease in the metabolic activity of the cells, which in turn may be responsible for suppressing antigondal effects of the pineal product(s) as would normally occur during the breeding period.

\section{References}

Ambadkar, P. M. \& Chauhan, B. C. 1976. Observations on reproductive cycle of Indian House Crow, Corvus splendens (Vieillot): I-Histomorphological study of annual testicular cycle. Pavo 14 (1 \& 2): 65-79.

Ambadkar, P. M. \& Chauhan, B. C. 1977. Observations on reproductive cycle of Indian House Crow, Corvus splendens (Vieillot): II-An ovarian cycle-a histomorphological and field study. Pavo 15 (1 \& 2): 48-72.

Anton-Tay, F. 1971. Pineal-brain relationships. In: The Pineal Gland (Wolstenholme, G. E. W., and Knight, J., eds.), pp. 213-220.

Axelrod, J., Wurtman, R. J. \& Winget, C. M. 1964. Melatonin synthesis in the hen pineal gland and its control by light. Cited in Wurtman et al. (1968), loc. cit.

Axelrod, J., Wurtman, R. J., \& Snyder, S. H. 1965. J. Biol. Chem. 240 : 949.

Barfuss, D. \& Ellis, L. 1971. Gen. Comp. Endocrinol. 17: 183.

Bargmann, W. 1943. Die Epiphysis cerebri. In: Handbuch der mikro sckopischen Anatomie des Menschen. (Von Molendroff, W., ed), Vol. VI, Part 4, pp. 309-502. Springer-Verlag, Berlin and New York.

Baumel, J. J. 1962. Asymmetry of encephalic arteries in the pigeon (Columba livia). Anat. Anz. 111: 91-102.

Beattie, C. W., \& Glenny, F. H. 1966. Some aspects of the vascularization and chemical histology of the pineal gland in Gulls. Anat. Anz. 118: 396-404.

Benninghoff, A. 1953. Das funktionelle kernodem als Indicator der zelltatigkeit. Mon. Zool. Ital., 61 : Suppl. 84-124.

Bindoni, M. \& Rizzo, R. 1965. Hippocampal evoked potentials and canvalsive activity after electrolytic lesions of the pineal body, in chronic experiments on rabbits. Arch. Sci. Biol. (Bologna) 49: 223233.

Binkley, S. 1980. Functions of the pineal gland, In: Avian Endocrinology (A. Epple and M. H. Stetson, eds.) pp. 53-74, Academic Press, New York, San Francisco.

Bischoff, M. B. 1967. Ultrastructural evidence for secretory and photoreceptor functions in the avian pineal organ. J. Cell. Biol. 85: 13A-14A.

Bischoff, M. B. 1969. Photoreceptoral and secretory structures in the avian pineal organ. J. Ultrastruct. Res. 28: 16-26.

Casperson, T. O. 1950. Cell-growth and cell-function. W. W. Norton, New York.

Chauhan, B. C. 1978. Ph. D. Thesis entitled 'Studies on some aspects of histophysiology of certain endocrine glands related to reproductive cycle of Indian house crow, Corvus splendens (Vieillot)' submitted to M. S. University of Baroda, Baroda, India.

Cheze, G. \& Kahaye, J. 1969. Etude morphologique de la region epiphysaire de Gambusia affinis holbrooki. Incidenses histologi ques de certain facteurs externes sur le toit diencephalique. Ann. Endocr. 30: 45-53.

Collin, J. P. 1966a. Contribution a L'etude des follicules de L'epiphyse embryonnaire d'Oiseau. C. R. Acad. Sci. Ser. C. 262: 2263-2266.

Collin, J. P. 1966b. Etude preliminaire des photorecepteurs rudimentaries de l'epiphyse de Pica pica L. peudant la vie embryonnaire et postembryonnaire. C. R. Acad. Sci., Ser. D. 263: 660-663.

Collin, J. P. 1966c. Sur l'evolution des photorecepterus rudimentaires epiphysaires chez la Pie (Pica pica L.) C. R. Soc. Biol. 160: 1876-1880. 
Collin, J. P. 1967a. Le photorecepteur rudimentaire de L'epiphyse d'Oiseau: Le prolongement basal chez la passereau Pica pica L. C. R. Acad. Sci. 265: 48-51.

Collin, J. P. 1967b. Nouvelles remarques sur l'epiphyse de quelques Lacertiliens et Oiseaux. C. R. Acad. Sci. 265 : 1725-1728.

Collin, J. P. 1968. Rubans circoncrits par des vesicules dan les photorecepteurs rudimentaries epiphysaries de l'Oiseau: Vanellus vanellus (L.) at nouvelles considerations phylogenet iques relatives aux pinealocytes (on cellules principales) des Mammiferes. C. R. Acad. Sci. 267: 758-761.

Collin, J. P. 1969. Contribution a l'etude de l'organe pineal. De l'epiphyse sensorielle a la glande pineale: Modalites de transformation et implications fonctionnelies. Ann. Sta. Biol. Besse-en-chandesse, Suppl. 1 : $1-359$.

Collin, J. P. 1971. Differentiation and regression of the cells of the sensory line in the epiphysis cerebri. In Pineal Gland, A CIBA Found. Symp. (C. C. E. Wolstenholme and J. Knight, eds.), 1971. pp. 79125, Churchill Livingstone, Edinburgh \& London.

Dodt, E. 1963. Photosensitivity of the pineal organ in the teleost, Salmo iridens (Gibbons). Experentia 19: $642-644$.

Dodt, E., Ueck, M. \& Okcshe, A. 1971. Relation of structure and function. The pineal organ of lower vertebrates. In: J. E. Purkyne Centeuary symposium, Prag., 1969. (Kruta, V., ed.), pp. 253-278. Univ. Jana Evangelisty Purkyne, Brno.

Eakin, R. M. \& Westfall, J. A. 1959. Fine structure of the retina in the reptilian third eye. J. Biophys. Biochem. Cytol. 6: 133-134.

Eakin, R. M. \& Westfall, J. A. 1960. Further observation on the fine structure of the parietal eye of lizards, Biophys. Biochem. Cytol. 8: 483-501.

Ellis, L. C. 1976. Endocrine role of the pineal gland. American Zoologist, (Suppl.) 16 (I), A. Quarterly Publication of the American Society of Zoologist.

Ellis, L. C. \& Balph, D. F. 1976. Age and seasonal differences in the synthesis and metabolism of testosterone by testicular tissue and pineal. HIOMT activity of Uinta Ground Squirrels (Spermophilus armatus), Gen. Comp. Endo. 28: 42-51.

Fiske, V. M., Bryant, G. K. \& Putman, J. 1960. Effect of light on the weight of the pineal in the rat. Endocrinol. 66: 489-491.

Fiske, V. M., J. Pound \& Putman, J. 1962. Effect of light on the weight of the pineal organ in hypophysectomized, gonadectomized, adrenalectomized or thioureacil fed rats. Endocrinology 71: 130-133.

Friedrich-Freska, H. 1932. Entwicklung, Bau und Bedentung det Parietalgegend bei Teleostern. Z. Wiss., Zool. 141 : 52-142.

Fujie, E. 1968. Ultrastructure of the pineal body of the domestic chicken, with special reference to the changes induced by altered photoperiods. Arch. Histol. Japo. 29: 271-303.

Gladstone, R. J. \& Wakeley, C. P. G. 1940. The Pineal Gland. Williams and Vilkins, Baltimore.

Hafeez, M. A. \& Ford, P. 1967. Histology and histochemistry of the pineal organ in the sockaye salmon, Oncorhynchus nerka walbaum, Can. J. Zool. 45: 117-126.

Hafeez, M. A. 1971. Light microscopic studies on the pineal organ in Teleost fishes with special regard to its functions. J. Morphol. 134: $281-314$.

Hartwig, H. G. 1980. 'The structure of the pineal gland', In: Avian Endocrinology (A. Epple and M. H. Stetson eds.). pp. 33-52, Academic Press, New York \& San Fransisco.

Hedlund, L., \& Ralph, C. L. 1967. Daily variations of pineal serotonin in Japanese quail and SpragueDawley rats. Amer. Zool. 7: 712 .

Hollman, P. 1962. Uber Herkunft and Bedeutung der gliosen Elemente in der Epiphysis cerebri. Untersuchung and Haussangetieren. Zentralbl. Veterinarmed., Ser. A. 10: 203-206.

Izawa, Y. 1925. Studies on the pineal body. O. On the post-natal growth of the pineal body of the albino rat with observations on its histology. J. Comp. Neur. 39: 1-17.

Kappers, J. A. 1960. The development, topographical relations and innervation of the epiphysis cerebri in the albino rat. Z. Zellforsch. Mikrosk. Anat. 52: 163-215.

Kappers, J. A. 1965. Survey of the innervation of the epiphysis cerebri and the accessory pineal organs of vertebrates, Progr. Brain Res. 10: 87-153. 
Kelly, D. E. 1962. Pineal organs: Photoreception, Secretion and development. American Scientist 50: 597-625.

Krabbe, K. H. 1961. La glande-World Neurology, 2: 94-102.

Krabbe, K. H. 1965. Development of the pineal organ and a rudimentary Parietal eye in some birds. J. Comp. Neurol. 103: 139-149.

Lauber, J. K., Boyd, J. E. \& Axelrod, J. 1968. Enzymatic synthesis of melatonin in Avian pineal body: Extraretinal response to light. Science 161 : 489-490.

Le Gros Clark. 1940. The nervous and vascular relations of the pineal gland. J. Anat. 74: 471-492.

McGeer, E. G. \& McGeer, P. L. 1966. Circadian rhythm in pineal tyrosine hydroxylase, Science 153: 73-74.

Menakar, M. \& Oksche, A. 1974. "The Avian Pineal Organ", In: Avian Biology, (Farner, D. S. and King, J. R. eds.,), Vol. IV, pp. 80-114. Academic Press, New York, London.

Menaker, M. \& Zimmerman, N. 1976. Role of the pineal in the circadian system of birds. American Zool. 16: 45-55.

Mikami, S. I. 1969. The morphology and fine structure of the pineal body of the chicken. In: Seminar on hypothalamic and endocrine functions in birds. (Kobayashi, H. and Farner, D. S., eds.), pp. 6970. Abstracts, Tokyo, Japan.

Morita, Y. 1966. Absence of electrical activity of the pigeon's pineal organ in response to light. Experentia 22: 402.

Nir, I., Behroozi, K., Assael, I., Ivriani, I. \& Sulman, F. G. 1969a. Changes in the electrical activity of the brain following pinealectomy. Neuroendocrinology 4: 122-127.

Nir, I., Hirschmann, N., Mishkinsky, J. \& Sulman, F. G. 1969b. The effect of light and darkness on nucleic acids and protein metabolism of the pineal gland. Life Science 8: 279-287. Part II.

Oksche, A. 1968. Zur Frage extraretinal $r$ photorezeptcren in pineal organ der Vogel. Arch. Anat. Histol. Embryol. 51 : 497-507.

Oksche, A. 1971. Sensory and glandular elements of the pineal organ. In: Pineal gland. Ciba Found. Symp. 1970, pp. 127-146.

Oksche, A., Farner, D. S., Serventy, D. L., Wolff, F., \& Nicholls, C. A. 1963. The hypothalamo-hypophysealneurosecretory system of the Zebra Finch, Taeniopygia castanotis. Z. Zellforsch. Mikrosk. Anat. 58: 846-914.

Oksche, A., \& Kirschstein, H. 1969. Elektronenmikroskopische untersuchungen am Pineal organ von Passer domesticus. Z. Zellforsch. Mikrosk. Anat. 102: 214-241.

Oksche, A., Kirschstein, H., Kobayashi, H. \& Farner, D. S. 1972. Electron microscopic and experimental studies of the pineal organ in the white-crowned sparrow, Zonotrichia leucophrys gambelii. $\mathrm{Z}$. Zellforsch. Mikrosk. Anat. 124: 247-274.

Oksche, A., Ueck, M., \& Rudeberg, C. 1971. Comparative ultrastructural studies of sensory and secretory elements in different pineal organs. Mem. Soc. Endocrinol. 19: 7-25.

Oksche, A., \& Vaupel-von Harnack, M. 1965a. Vergleichende elektronenmikroskopische studien am Pineal organ. In: Structure and Function of the Epiphysis Carebri. (Kappers, J. A. and Schade, J. P., eds.), pp. 237-258. Elsevier, Amsterdam.

Oksche, A. \& Vaupel-von Harnack, M. 1965b. Uber rudimentare sinneszell-strukta renim Pineal organ des Huhnchens. Naturwissenschaften 52: 662-663.

Oksche, A. \& Vaupel-von Harnack, M. 1966. Elektronenmikroskoskopische untersuchungen zur Prage der sinneszellen im Pineal organ der Vogel. Z. Zellforsch. Mikrosk. Anat. 69: 41-60.

Pang, S. 1971. Histological study of the pineal gland of scrub jays, Aphelocoma coerulescens. M. A. Thesis in Biology, Chico State College, Chico, California, U. S. A.

Prop, N. \& Ebels, T. 1968. Acta Endocrinol. 57: 585.

Quay, W. B. 1961. Reduction of mammalian pineal weight and lipid during continuous light. J. Gen. Comp. Endocrinol. 1: 211-217.

Quay, W. B. 1963. Circadian rhythm in rat pineal serotonin and its modifications by estrous cycle and photoperiod. Gen. Comp. Endocrinol. 3: 473-479.

Quay, W. B. 1965a. Histological structure and cytology of the pineal organ in birds and mammals, In: 
Structure and Function of the Epiphysis Cerebri. (Kappers, J. A. and Schade, J. P., eds.) pp. 49-86, Elsevier, Amsterdam.

Quay, W. B. 1965b. Experimental evidence for pineal participation in homeostasis of brain composition. Prog. Brain Res. 10: 646-653.

Quay, W. B. 1966. Pineal structure and composition in red and grey kangaroos. Anat. Rec. 154: 405.

Quay, W. B. 1970a. Endocrine effects of the mammalian pineal. American Zoologist 10: 237-246.

Quay, W. B. 1970b. Physiol. Behav., 5: 353 and 1281.

Quay, W. B. 1972a. Pineal vasoconstriction at daily onset of light: its physiological correlates and control. The Physiologist 15: 241.

Quay, W. B. 1972b. Twenty-four hour rhythmicity in carbonic anhydrase activities of choroid plexuses and pineal gland. Anat. Rec. 174: 279-287.

Quay, W. B. 1973. Retrograde perfusion of the pineal vascular routes to brain and choroid plexus. Amer. J. Anat. 137: 387-400.

Quay, W. B. 1974. Pineal chemistry in Cellular and Physiological Mechanisms. Charles C. Thomas, Springfield.

Quay, W. B. \& Renzoni, A. 1966. Growth 30:315.

Quay, W. B. \& Renzoni, A. 1967. The diencephalic relations and variably bipartile structure of the avian pineal complex. Rev. Biol. 60: 9-75.

Ralph, C. L. 1970. Structure and alleged functions of avian pineals. Amer. Zool. 10:217-235.

Ralph, C. L. 1978. Prog. Reprod. Biol. 4: 30-37.

Ralph, C. L., Hedlund, L. \& Murphy, W. A. 1967. Diurnal cycles of melatonin in bird pineal bodies. Comp. Biochem. Physiol. 22: 591-599.

Ralph, C. L., \& Dawson, D. C. 1968 . Failure of the pineal body of two species of birds (Coturnix coturnix japonica and Passer domesticus) to show electrical responses to illumination. Experentia 24:147148.

Ralph, C. L. \& Lane, K. B. 1969. Morphology of the pineal body of wild House sparrows (Passer domesticus) in relation to reproduction and age. Can. J. Zool. 47: 1205-1208.

Renzoni, A. 1965a. L'epifisi nel Melopsittacus undulatus, Riv. Biol. 48: 343-364.

Renzoni, A. 1965b. Ancora sull'epifisi delgi uccelli. Boll. Zool. 32: 743-749.

Renzoni, A. 1970. Developmental morphology of the pineal complex in doves and pigeons (Aves: Col umbidae). Z. Zellforsch. Mikrosk. Anat. 104: 19-28.

Renzoni, A., Eakin, R. M., \& Quay, W. B. 1968. Cilia of modified structure in avian pineal organs, Elec tron Microsco., 1968, Proc. Eur. Reg. Conf., 4th, pp. 563-564.

Reiter, R. J., 1980. The pineal and its hormone in the control of reproduction in mammals. Endocr. Rev. 1 : 109.

Roth, W. D., Wurtman, R. J., \& Altschule, M. D. 1962. Morphologic changes in the pineal parenchyma cells of rats exposed to continuous light or darkness. Endocrinology 71: 888-892.

Saylor, A. \& Wolfson, A. 1968. Role of the eyes and superior cervical ganglia on the effects of light on the pineal and gonads of the Japanese quail. Arch. Anat. Histol. Emblyol. 51, 615-626.

Saylor, A. \& Wolfson, A. 1969. Hydroxyindole-O-methyl transferase (HIOMT) activity in the Japanese quail in relation to sexual maturation and light. Neuroendocrinology 5 : 322-332.

Shellabarger, C. J. 1952. Pinalectomy VS. pineal injection in young cockrel. Endocrinology 51: 152 154.

Smith, A. R. 1971. The topographical relations of the rabbit pineal gland to the large intracranial veins. Brain Res. 30: 339-348.

Spiroff, B. E N. 1959. Embryonic and post-hatching development of the pineal body of the domestic fowl. Amer. J. Anat. 103: 375-401.

Srebro, A. 1967a. The choroid plexus of frogs in natural and experimental conditions. Folia Biol. 14: 89.

Srebro, A. 1967b. The subfornical organ in frogs and its role in the regulation of the secretory activity of the paraphysis. J. Hirnforsch. 9: 397-402.

Stalsberg, H. 1966. Effects of extirpation of the epiphysis cerebri in 6-day old embryos. Acta. Endocri- 
nol. 48: Suppl. 97: 1-119.

Studnicka, F. K. 1905. Parietal organe. In: Lehrbuch der vergleichenden mikroslopischen Anatomie der wirbeltiere. (Oppel, A., ed.), Part 3, pp. 1-248, Fischer, Jena.

Szenthagothai, J., Flerko, B. Mess, \& Halasz, B. 1968. "Hypothalamic control of the anirior pituitary", pp. 118-134, Akademiai Kiad, Budapest.

Takashi, I., \& Matsushima, S. 1967. A quantitative morphological study of the post-natal development of the pineal body of the Mouse. Anat. Rec. 159: 447-452.

Talanti, S. 1967. The effect of thiouracil, excess thyroxine and thyroidectomy on the ependymal cells with special reference to the subcommisural organ. Anat. Rec. 159: 379-386.

Tilney, F., \& Warren, L. F. 1919. "The morphology and evolutional significance of the pineal body". Amer. Anat. Mem., No. 9, Wistar Institute, Philadelphia, Pennsylvania, U. S. A.

Tomatis, M. E. \& Orias, R. 1967. Acta Physiol. Lat. Amer, 17: 227.

Von Bartheld, F. \& Moll, J. 1954. The vascular system of the mouse epiphysis with remarks on the comparative anatomy of the venous trunks in the epiphyseal area. Acta. Anat. 22: 227-235.

Wurtman, R. J., Roth, W., Altschule, M. \& Wurtman, J. 1961. Acta Endocrinol. 36: 617. Cited in Wurtman et al., 1963. loc. cit.

Wurtman, R. J., Axelrod, J., \& Chu, E. W. 1963. Melatonin-a pineal substance, effect on rat ovary. Science $141: 277-278$.

Wurtman, R. J., Axelrod, J., \& Fischer, J. E. 1964. Melatonin synthesis in the pineal gland, effect of light, mediated by the sympathetic nervous system. Science 143: 1328-1330.

Wurtman, R. J., Axelrod, J., \& Kelly, D. E. 1968, " "The Pineal”, Academic Press, New York.

\section{年周期におけるイエガラス Corvus splendens (Viellot) の松果腺についての観察}

イエガラスの松果腺について, 季節に伴う組織学的変化と, 先の構造の詳細について調べた。

イエガラスの松果腺は他の脊椎動物にみられるよらな繳密な小葉型のものと小翼型のものとの中間的な,

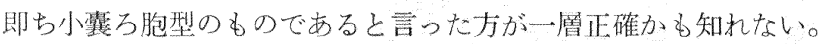

異った細胞型と神経供給について解剖学的観察を行った。松果腺の重量の年周変化と核数の变化につい て観察し，变たそれと，日長と生殖腺活動における同時的な変化との相互関連性を調べた。この松果腺の 活動は生殖腺が，退行し非繁殖状態の時（短日支配）の方が，繁殖状態の時（長日交配）より活発である ことが観察された。

体積の変化は松果腺の活動状態を判定するのにそれ程の重要性のないことが分った。

B.C. Chauhan \& P. M. Ambadkar: バロダ大学理学部動物学教空神経内分泌学研究坴 


\section{PLATE I}

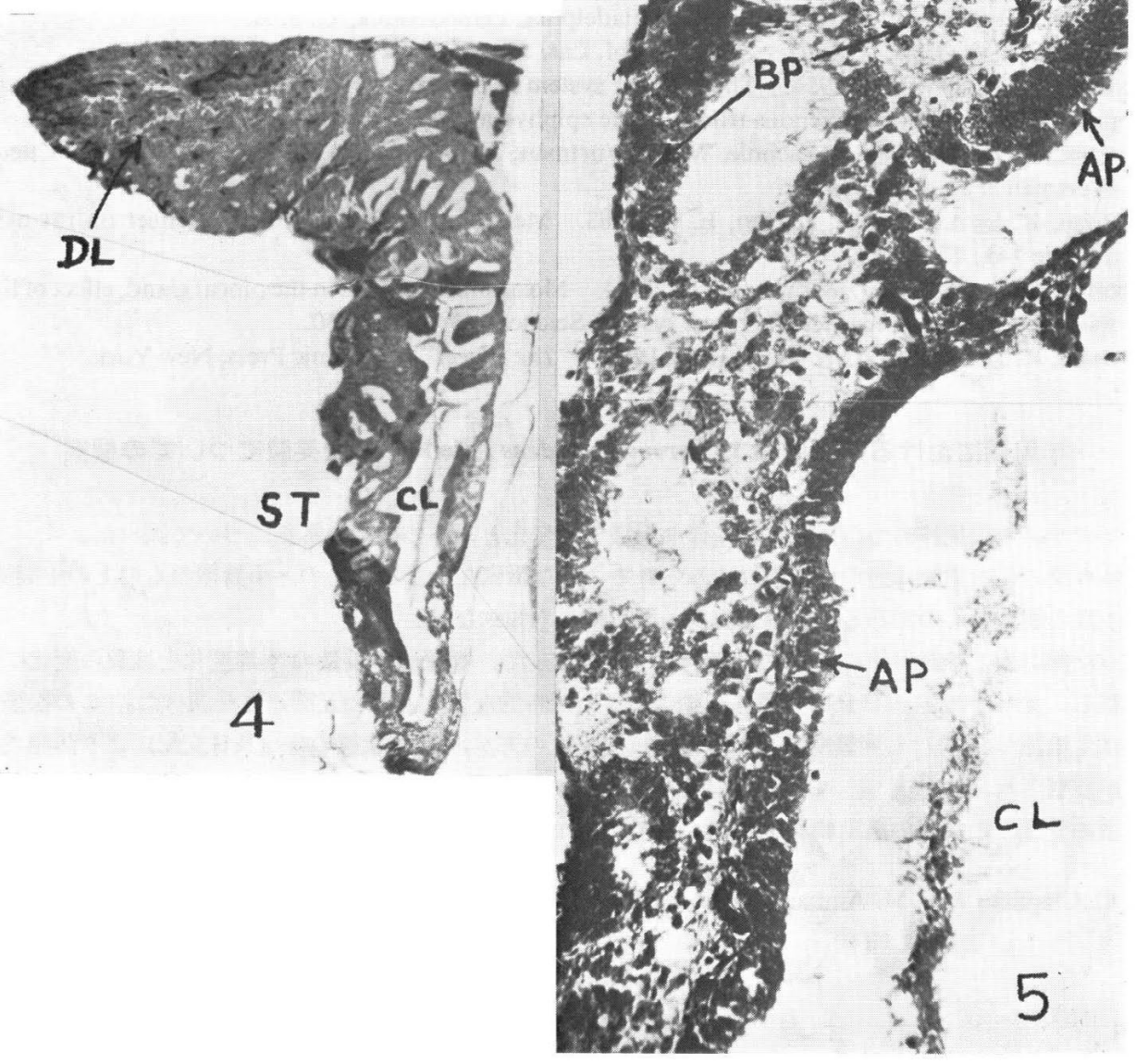

Fig. 4. Parasagittal section of the pineal showing the form and structure of the gland. Note 'Sacculofollicular' form of pineal. Proximal part (stalk) (ST) having central lumen (CL) which does not cummunicate with the third ventricle. Scalloped epithelial lining is also visible Distal part (DP) having comparatively 'solid' form due to compact follicular arrangement of pinealocytes and absence of central lumen in that part. $\times 25$.

Fig. 5. Parasaggital section of the stalk of the pineal at a higher magnification showing details of scalloped epithelial lining. $\alpha$-Pinealocytes (AP), $\beta$-pinealocytes (BP), darkly stained nuclei of erythrocytes (ER) \& fibroblasts (FBR) are visible. $\times 95$. CL-Central Lumen. 
PLATE II

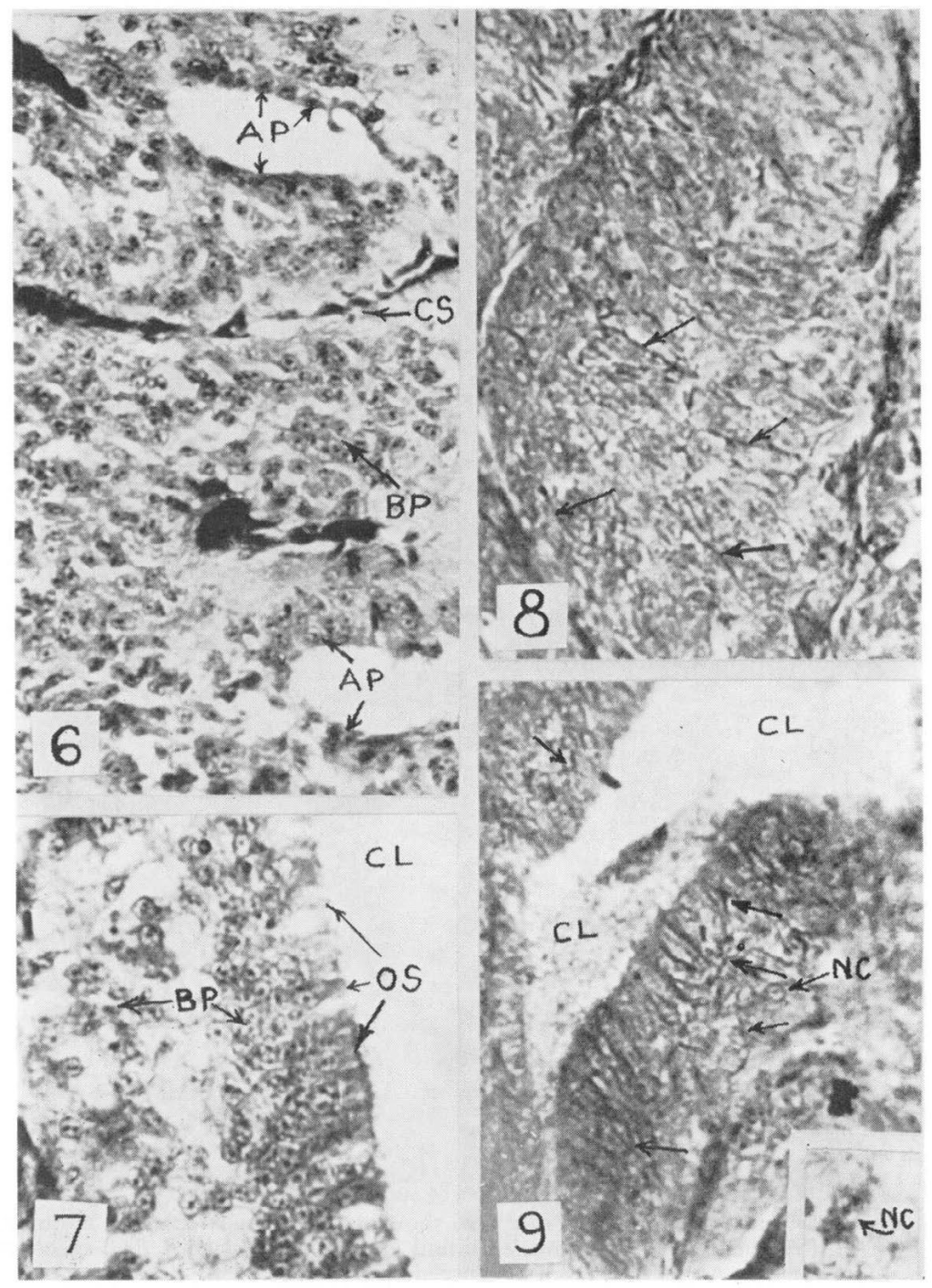

Fig. 6. Section through distal part of pineal showing low epithelium due to reduced (vestigial) outer segments of $\alpha$-pinealocytes (AP) lining the follicular lumen. $\beta$-pinealocytes (BP) are comparatively more than in the stalk region. Note darkly stained connective tissue septa $(\mathrm{CS}) . \quad \times 250$.

Fig. 7. An area from the wall of stalk depicting taller epithelium due to prominent but vestigial outer segments (OS) of $\alpha$-pinealocytes. Compare this photomigrograph with Fig. 6 and inset with Fig. 12. Note subsequent layers of small $\beta$-pinealocytes (BP) (parenchymal cells). $\quad \times 260$. CL-Central Lumen.

Fig. 8. Section through a distal part of the pineal showing fine nerve fibres (arrows) running around the cells and in the septa (Protargol-silver). $\times 250$.

Fig. 9. Section through a stalk of the pineal. Note dichotomous basal processes of nerve fibres (arrows) among epitheloid parenchyma cells. Inset showing a large nerve cell body. Such nerve cells are located in basal region of pineal stalk (Protargolsilver) (CL-Central Lumen), $\quad \times 250 . \quad$ NC-Nerve Cell. 
PLATE III

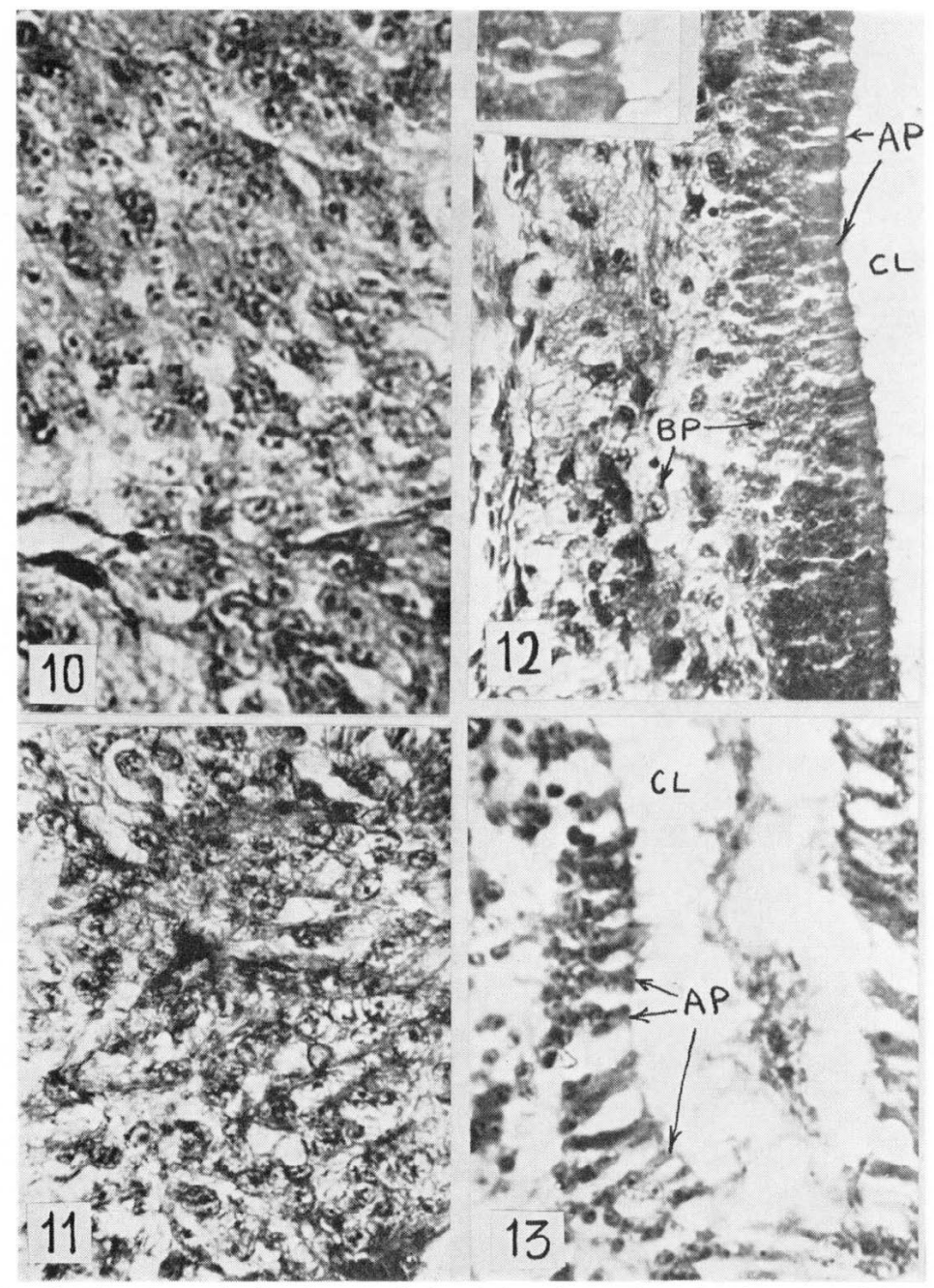

Fig. 10. Section through distal part of pineal showing active pinealocytes. Note rounded healthy nuclei, prominent nucleioli and granular cytoplasm. The specimen was collected in August i.e. from non-breeding phase. $\times 350$.

Fig. 11. Section through distal part of pineal showing less active pinealocytes. Cells exhibit vacuolated, agranular cytoplasm and indistinct cell-boundries are notable features of these cells. Also visible are some vesicular and few crumpled nuclei. The specimen was collected in June. i.e. during breeding phase (compare this photomicrograph with Fig. 10) $\times 375$.

Fig. 12. Parasagittal section of pineal stalk. Note active $\alpha$-pinealocytes (AP) with prominent but vestigial outer segments and well maintained integrity of the epithelium. Also seen are $\beta$-pinealocytes (BP) with prominent nuclei. Inset shows magnified view of one of the $\alpha$-pinealocytes. This specimen was collected in August i.e. during non-breeding phase. $\times 225$. CL-Central Lumen.

Fig. 13. Parasagittal section of pineal stalk. $\alpha$-pinealocytes (AP) have become loose. Outer segment have been partially descarded in the central lumen (CL). Note cell debris in CL. Integrity of epithelium is not maintained. Other cells of pineal have also become sparse and have stained darkly. This specimen was collected in June i.e. during breeding phase (Compare this photomicrograph with Fig. 12). $\times 250$. 